\title{
Model-based tests on the time of crew evacuation from the danger area in an excavated underground mine heading
}

\author{
Magdalena Tutak $^{1 *}$, and Tatiana Gvozdkova ${ }^{2}$ \\ ${ }^{1}$ Silesian University of Technology, Faculty of Mining, Safety Engineering and Industrial \\ Automation, Akademicka 2A, 44-100 Gliwice, Poland \\ ${ }^{2}$ T.F. Gorbachev Kuzbass State Technical University, 650000, 28 Vesennyaya St., Kemerovo, Russia
}

\begin{abstract}
When ventilation hazards become active in an underground mine heading, it is very often necessary to evacuate the crew from the danger area. This evacuation is carried out along emergency escape (evacuation) routes to a heading which is not affected by a given incident. Such a heading must provide access to fresh air and guarantee that there is no smoke. In this context, an important role is played by the time in which the crew leaves the danger area and gets into the safety zone. The time needed by the crew to cover the length of an escape route depends on a number of factors. In hard coal mines, the time necessary to evacuate the crew is most commonly determined on the basis of analytical methods developed in the second half of the 20th century. In recent years, however, the development of numerical methods has made it possible to determine these times using model-based tests supported by numerical simulations. The article presents the results of such tests with regard to the evacuation of a crew from an excavated dog heading. The objective of the tests was to analyse how the movement speed of the miners being evacuated from the danger area affects the time of their evacuation. The analysis was carried out for four different movement speeds of a crew and for 26 miners working in the heading under analysis. Their distribution in the heading reflected the actual location of their work stations. The results obtained made it possible to determine the times and intensity of their evacuation, and they should also serve as a valuable source of information for the emergency rescue teams in underground mines.
\end{abstract}

\section{Introduction}

There are numerous threats in the underground headings of hard coal mines [1-13]. The most dangerous include ventilation hazards, which are usually characterised by dynamic development. Ventilation hazards include methane hazards, fire hazards and coal dust explosion hazards, as well as sudden outbursts of gases into mine headings. If any of those occurs in an underground mine heading, it is very often necessary to evacuate the crew

\footnotetext{
*Corresponding author: Magdalena.tutak@polsl.pl
} 
from the danger area. The miners are then evacuated along previously identified and properly marked emergency escape routes.

An emergency escape route in an underground mine is a system of interconnected headings used by crews to withdraw from the place where a dangerous incident has occurred or from the danger zone into a safe heading. A safe heading is one where the air flow is free from any poisonous and harmful gases and other detrimental substances (emitted, for example, as a result of combustion into the heading's atmosphere), and from which crews can be safely evacuated to the surface. The evacuation of a crew from a mine heading under threat via emergency escape routes represents the basis of safety and security, and its efficiency depends on a number of factors. These factors can be divided into human factors (e.g. being familiar with the emergency escape route, the movement speed, the reaction to the conditions present in the heading, the health status, etc.) and technical factors, which include the length of emergency escape routes, the geometric parameters and inclination of headings, as well as the equipment and obstacles present in such headings [14, 15]. Additionally, there are environmental factors, such as the temperature, humidity, smoke levels and composition of the mine atmosphere.

One of the basic obligations of the Managers of Mining Plants is to determine emergency escape routes, as defined in applicable legal regulations [16]. The basic parameter for determining such routes is their width, which should be greater than $0.7 \mathrm{~m}$.

A properly designated emergency escape route should allow the evacuees to cover its distance within a time not longer than the operating time of the self-contained self-rescue devices (SCSR), which currently ranges from approx. 50 to 60 minutes). If the time necessary to cover this route is longer than the operating time of the self-contained selfrescue devices, it is mandatory to deploy change-over stations along its length, where the crew can change the devices for ones that make it possible to cover the remaining sections of the route. Evacuation is carried out to a place with no smoke in the air flow, where it is possible to breathe freely and safely.

The most common tools used in hard coal mines for determining the crew evacuation times and the passage of miners along the designated emergency escape route are based on analytical methods. These methods include the ones by Kozdrój [17], Kocka [18] Walkiewicz [19], and the method developed by the Central Mining Institute in Katowice [20]. A common feature of all these methods is the manner of determining the movement time of workers via emergency escape routes. It involves identifying the average passage time of a crew for different inclination angles of the heading, as well as for the presence or absence of smoke. The average passage time in these methods was determined on the basis of multiple passages of miners along the headings at hand. These studies were conducted in 1970 s and 1980s and their results have been used ever since to determine the evacuation times. Despite being based on the results of real-world tests, the times determined very often depart from those noted during rescue operations. Most commonly, these times are underestimated, which represents a huge risk for the withdrawing crew, especially if it is necessary to determine the location of change-over stations, where self-contained selfrescue devices are changed.

For this reason, it is necessary to conduct research in order to be able to provide the best estimation of the crew evacuation times from the danger area. In this respect, model-based tests with numerical analyses have become increasingly applicable over recent years. They are successfully used for determining emergency escape and evacuation routes and their optimisation in facilities other than mines.

As the literature to date has not discussed the application of such methods to underground headings, it seems reasonable to conduct an analysis which will make it possible to determine the evacuation time of a crew from the heading under threat, using numerical simulation. Such analyses were carried out for a real-world, excavated dog 
heading with a length of 500 metres and 26 miners working in it. It was assumed that the crew must be withdrawn from the heading due to fire in the mine face area. The tests were carried out for four different movement speeds of individuals. The purpose of the tests was to identify the impact of the movement speed on the evacuation time of workers from the danger area. The results obtained for the multivariate analysis allow for assessing the evacuation time for a wide range of movement speeds of the crew. This, in turn, helps to plan a rescue operation if a given incident occurs.

\section{Materials and method}

The evacuation time of a crew from an excavated dog heading was analysed using the numerical tools offered by Pathfinder. This programme makes it possible to create numerical simulations concerning people's evacuation from buildings, as well as mine headings, and determine the time range within which a given evacuation process is carried out.

Pathfinder is a software tool for simulating the behaviour of crowds and modelling complex evacuation scenarios [21]. It also helps to determine the time necessary to safely exit the building or other facility under analysis. In order to determine the evacuation time, the programme uses the algorithms of artificial intelligence (AI). These algorithms also allow for determining the personality traits for the simulation participants (persons) and the possibility of making individual decisions by those participants. Pathfinder visually represents individuals as $3 \mathrm{D}$ objects. The algorithms implemented in the programme make it possible to visualise the actual flow of the individuals evacuated along an emergency escape (evacuation) route. The variable-control technology of individuals' movement implemented in Pathfinder makes it possible to choose such partial directions of movement for model evacuees that their individual evacuation time is as short as possible. This model also takes into account the possibility of collision along the emergency escape route and the inertia of individuals.

The analysis, whose purpose was to determine the impact of the movement speed of a crew escaping from the excavated mine heading, was based on a model which takes into consideration the length of the heading, its width and equipment, as well as the distribution of the particular individuals.

The usual movement speed along horizontal evacuation routes assumed for pedestrian traffic amounts to $1.2 \mathrm{~m} / \mathrm{s}$ [22-24].This speed is defined as the ratio of the evacuation distance covered by a person to the evacuation time [25]. The literature also indicated other speed values, e.g. $1.19 \mathrm{~m} / \mathrm{s}$ according to [21-23], or $1.7 \mathrm{~m} / \mathrm{s}$ for men and $0.8 \mathrm{~m} / \mathrm{s}$ for women according to [26]. The movement speed of the evacuees changes in the case of smoke presence along the evacuation route. According to [27], when the level of smoke is low (visibility ranging from 10 to $12 \mathrm{~m}$ ), the movement speed of individuals is $0.8-0.9 \mathrm{~m} / \mathrm{s}$, and when the level of smoke is high (visibility ranging from 3 to $5 \mathrm{~m}$ ), the individuals move at approx. $0.6-0.8 \mathrm{~m} / \mathrm{s}$ [27]. On the other hand, according to, for visibility ranging from 5 to $10 \mathrm{~m}$, the movement speed along horizontal evacuation routes is approx. $0.96 \mathrm{~m} / \mathrm{s}$, while up the stairs $-0.62 \mathrm{~m} / \mathrm{s}$. For visibility between 3 and 7 metres, these speeds amount to 0.64 $\mathrm{m} / \mathrm{s}$ and $0.53 \mathrm{~m} / \mathrm{s}$ respectively [27].

In the case at hand, it was assumed that the movement speeds of a crew equal to $0.6 \mathrm{~m} / \mathrm{s}$ and $0.8 \mathrm{~m} / \mathrm{s}$ corresponded to the evacuation conditions with the presence of smoke, whereas the movement speeds of a crew amounting to $1.0 \mathrm{~m} / \mathrm{s}$ and $1.2 \mathrm{~m} / \mathrm{s}$ corresponded to the conditions where the presence of smoke was insignificant or non-existent. The basic parameters of the calculation model are presented in Table 1. Figure 1, on the other hand, presents the geometric model of the heading under analysis, with the distribution of the particular crew members (top view). The model presented in Figure 1 is divided into 60- 
metre sections (from A to $\mathrm{G}$ ) and 40-metre sections (from $\mathrm{H}$ and I). A road header was also marked in the initial section of the heading (I), while a belt conveyor is visible along the entire length of the heading.

The model thus developed was subjected to a numerical analysis.

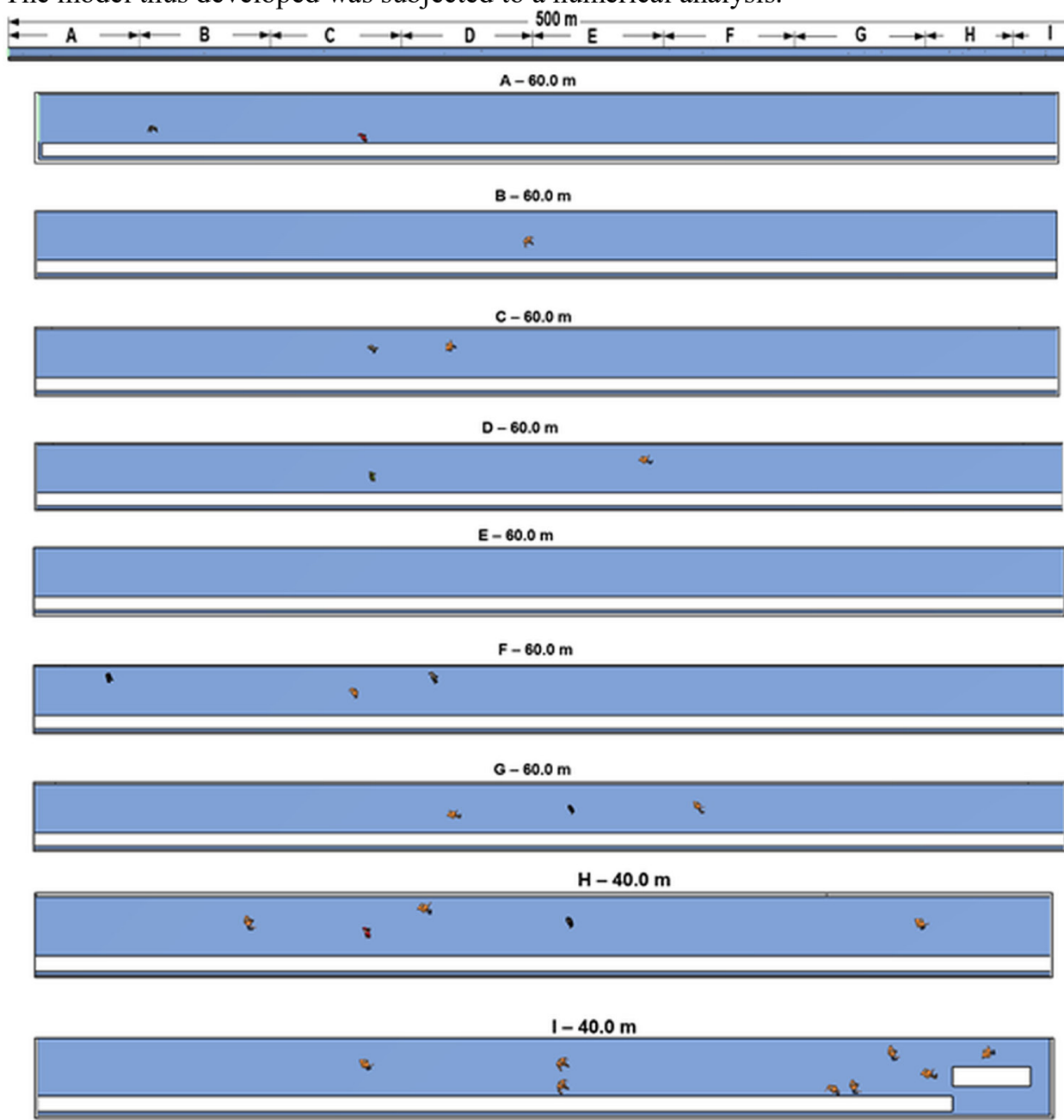

Fig. 1. The geometric model of the heading under analysis, with the distribution of the particular crew members (a top view).

Table 1. Basic parameters of the calculation model.

\begin{tabular}{|l|l|}
\hline The length of the excavation, $\mathrm{m}$ & 500 \\
\hline The width of the excavation, $\mathrm{m}$ & 4 \\
\hline The number of people staying in the excavation & 25 \\
\hline Average walking speed, $\mathrm{m} / \mathrm{s}$ & $0.6 / 0.8 / 1.0 / 1.2$ \\
\hline Time step, $\mathrm{s}$ & 0.025 \\
\hline
\end{tabular}




\section{Research results}

The calculations performed served as the basis for determining the evacuation times of a crew from the danger area. These times were determined for various movement speeds of a crew withdrawing from this area. These speeds are constant and apply to all workers. The fundamental information on the results obtained in terms of the evacuation time for the variants in question are presented in Table 2.

Table 2. The results of the tests performed.

\begin{tabular}{|c|c|c|c|c|}
\hline $\begin{array}{c}\text { Average walking } \\
\text { speed }\end{array}$ & $\begin{array}{c}\text { First person } \\
\text { evacuation time }\end{array}$ & $\begin{array}{c}\text { Evacuation time } \\
\text { of the last person }\end{array}$ & $\begin{array}{c}\text { Average } \\
\text { evacuation } \\
\text { time }\end{array}$ & $\begin{array}{c}\text { Standard } \\
\text { deviation }\end{array}$ \\
\hline $\mathrm{m} / \mathrm{s}$ & \multicolumn{5}{|c|}{$\mathrm{sec}$} \\
\hline 0.6 & 12.2 & 828.9 & 572.1 & 259.6 \\
\hline 0.8 & 9.3 & 621.8 & 429.2 & 194.7 \\
\hline 1.0 & 7.6 & 497.6 & 343.5 & 155.7 \\
\hline 1.2 & 6.4 & 414.7 & 286.4 & 129.9 \\
\hline
\end{tabular}

Based on the calculations made, it is possible to conclude that the movement speed of a crew, which depends on the conditions present in the heading, such as the presence or absence of smoke, significantly affects the total evacuation time of all the crew members from the heading under threat. Obviously, the higher the movement speed, the faster they leave the danger area.

Figure 2 presents the number of crew members evacuated from the heading as a function of analysis time, while Figure 3 shows the volume (flow rate) of the evacuees at the "outlet" from the heading in the subsequent seconds of the analysis (evacuation).

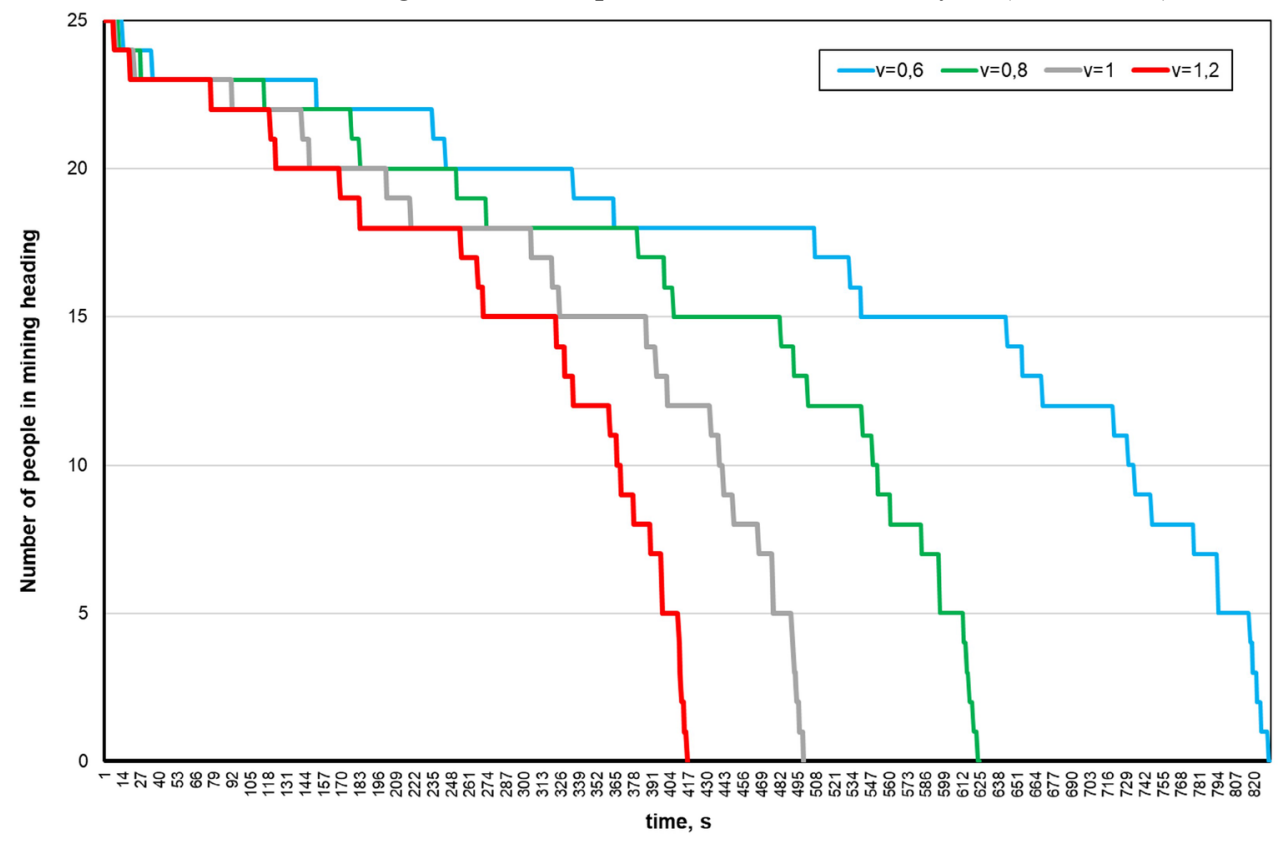

Fig. 2. The temporal relationship of the number of crew members evacuated from the heading under analysis for the assumed movement speeds of individuals. 
a

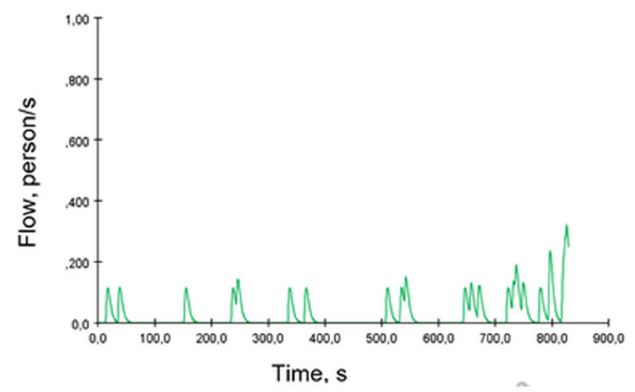

C

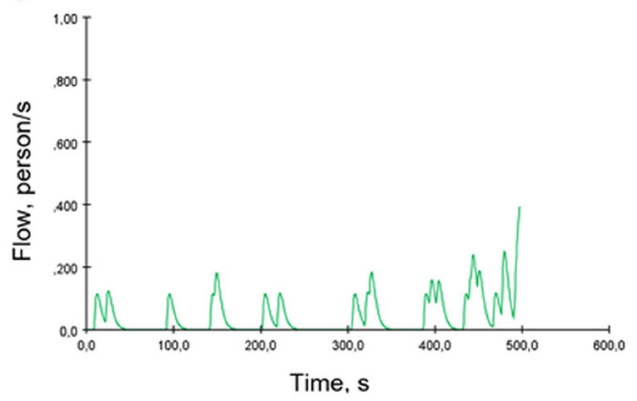

$\mathrm{b}$

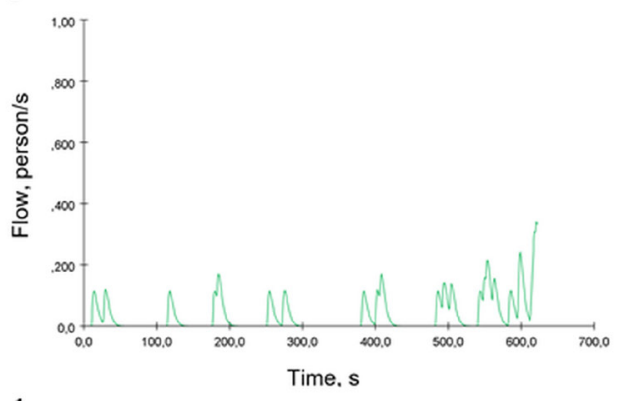

d

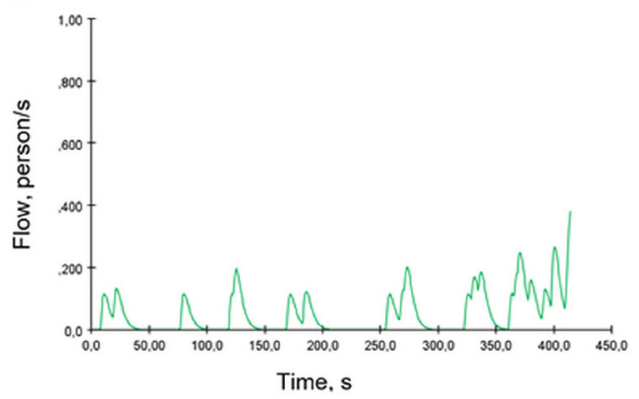

Fig. 3. The volume (flow rate) of the evacuees at the "outlet" from the heading in the subsequent seconds of the analysis (evacuation) for the assumed movement speeds of individuals (a-average walking speed $0.6 \mathrm{~m} / \mathrm{s}$; b-average walking speed $0.8 \mathrm{~m} / \mathrm{s} ; \mathrm{c}$-average walking speed $1.0 \mathrm{~m} / \mathrm{s} ; \mathrm{d}$-average walking speed $1.2 \mathrm{~m} / \mathrm{s}$ )

\section{Conclusion}

Mining exploitation is inextricably linked to a number of threats, including natural, technical and organisational. In the majority of cases, the occurrence of dangerous incidents related to those threats makes it necessary to evacuate the crew. In the case of dangerous incidents related to the ventilation hazard, in particular, the only way of safeguarding the crew is to quickly evacuate it to a safe area. However, to avoid tragedy, this process must be carried out smoothly and the workers must know how to behave and where to move. Identifying safe emergency escape routes and making employees familiar with them is one of the basic responsibilities of each employer.

The tests and their results allow for a multivariate analysis of evacuation parameters for various conditions of its occurrence. The dog heading under analysis is $500 \mathrm{~m}$ long. As a result, the crew working in the face must cover the whole distance, for example, when a fire occurs. By analysing the impact of their movement speed on the evacuation time, it is possible to forecast the necessary measures to protect them. The results obtained also provide a significant didactic aspect. The workers should be familiarised with them and trained on the necessary behaviours in the event of such incidents as fires.

The assumed objective of the paper was achieved. The model developed served as the basis for determining the evacuation times of a crew from this heading. The analysis was conducted for four movement speeds of a crew, which corresponded to the evacuation conditions in and without the presence of smoke.

The calculations performed make it possible to conclude that the movement speed of a crew amounting to $0.6 \mathrm{~m} / \mathrm{s}$, which corresponds to evacuation under heavy smoke 
conditions, doubles the evacuation time compared to the conditions under which the movement speed corresponds to the evacuation conditions without smoke.

The model developed and the tool used offer great opportunities in terms of analysing emergencies and the related necessity to evacuate the workers. There is no doubt that the results obtained should be used for the development of safety procedures in the process of mining exploitation.

\section{References}

1. D. Szurgacz, L. Sobik, J. Brodny, E3S Web Conf., 105, 01013 (2019)

2. M. Tutak, J. Brodny, Energies, 12(20), 3840 (2019)

3. D. Szurgacz, J. Brodny, Energies, 12(20), (2019)

4. J. Brodny, M. Tutak, Arch. Control Sci., 29(1), 25-39 (2019)

5. M. Tutak, J. Brodny, Appl. Sci. 9(24), 5315 (2019). DOI:doi.org/10.3390/app9245315

6. M. Tutak, J. Brodny, Energies 12(20), 3840 (2019). DOI:doi.org/10.3390/en12203840

7. M. Tutak, J. Brodny, Int. J. Environ. Res. Public Health 16(8), 1406 (2019). DOI:doi.org/10.3390/ijerph16081406

8. J. Brodny, M. Tutak, J. Appl. Fluid Mech. 11(3), 545-553 (2018).

9. J. Brodny, M. Tutak, Int. J. Environ. Res. Public Health 15(9), 1846 (2018) DOI:doi.org/10.3390/ijerph15091846

10. P. Małkowski, Ł. Ostrowski, J. Brodny, J. Sustain. Min. 17(3), 145-157 (2018)

11. D. Szurgacz, J. Brodny, E3S Web Conferences, 29, 00006 (2018)

12. M. Tutak, J. Brodny, IOP Conf. Ser. Earth Environ. Sci., 95, 042025 (2017)

13. M. Tutak, J. Brodny, IOP Conf. Ser. Earth Environ. Sci., 95, 042026 (2017)

14. J. Sułkowski et al. Badania prędkości poruszania się górników wyrobiskami podziemnymi symulujacymi drogi ucieczkowe w czasie pożaru (Report, Gliwice, 1993)

15. J. Sułkowski et al. Badania oceny dróg ucieczkowych w kopalniach węgla (Report, Gliwice, 1994)

16. Regulation of the Minister of Energy. URL: http://prawo.sejm.gov.pl/isap.nsf/DocDetails.xsp?id=WDU20170001118

17. M. Kozdrój, Zeszyty Problemowe Górnictwa, 2(2), (1964)

18. F.J. Kock, Selbstretungstechnik im Steinkohlebergbau (ATEU, Leoben, 1982)

19. W. Walkiewicz, Bezpieczeństwo Pracy w Górnictwie, 1, 1 (1983)

20. Metoda oceny dróg ucieczkowych w kopalniach węgla (Cental Mining Institute, Krakow, 1970)

21. Pathfinder Software, URL: https://www.thunderheadeng.com/wpcontent/uploads/downloads/2014/10/users_guide.pdf

22. R. Kosiński, A. Grabowski, Bezp. Pracy, 1, 20-25 (2013)

23. U. Chattaraj, U. Chakroborty, A. Subhashini, Procedia - Social and Behav. Sci., 104, 668-677 (2013)

24. S. Ko, M. Spearpoint, A. Teo, Fire Safety J., 42, 91-105 (2007)

25. Z.M. Fang, W.G. Song, Z.J. Li, W. Tian, W. Lv, J. Ma, J. Xiao, Build. Environ., 47, 316-321 (2012)

26. P. Thompson, D. Nilsson, K. Boyce, D. McGrath, Fire Safety J., 78, 251-261 (2015) 
27. G.J. Jeon, J.Y. Kim, W.H. Hong, Augenbroe G., Build. Environ., 46, 1094-1103 (2011) 